\title{
Variation in cell volume and community composition of bacteria in response to temperature
}

\author{
Johanna Sjöstedt $^{1, *}$, Åke Hagström ${ }^{1}$, Ulla Li Zweifel ${ }^{2}$ \\ ${ }^{1}$ Department of Natural Sciences, Linnaeus University, 39182, Kalmar, Sweden \\ ${ }^{2}$ Department of Cell and Molecular Biology, University of Gothenburg, 40530 Göteborg, Sweden
}

\begin{abstract}
Although temperature is a key parameter controlling the activity and growth of all microorganisms, information about how water temperature may structure the bacterioplankton community is not consistent. We examined the relationship between temperature and the community composition, cell volume, and morphology of marine bacterioplankton in 4 continuous cultures harbouring multispecies communities. All 4 cultures were maintained at a turnover time of $0.04 \mathrm{~h}^{-1}$ but at different temperatures of $10,15,20$, and $25^{\circ} \mathrm{C}$. Denaturing gradient gel electrophoresis analyses showed that the community composition shifted in response to temperature. Cell volumes were determined from digital photomicrographs using an image analysis program, which also allowed the identification of 3 morphological types of bacteria: cocci-, rod-, and vibrio-shaped bacteria. Mean bacterial cell volume decreased with increasing temperature, e.g., by $39 \%$ when the temperature was increased from $10^{\circ} \mathrm{C}$ to $20^{\circ} \mathrm{C}$. When the temperature increased, the bacterial morphology also shifted from dominance by rod- and vibrio-shaped bacteria to dominance by coccoid bacteria. The results clearly indicate the potential role of temperature in driving the community succession of bacterioplankton and in selecting for smaller cells at higher temperatures.
\end{abstract}

KEY WORDS: Temperature $\cdot$ Cell volume $\cdot$ Bacterioplankton $\cdot$ Morphology

\section{INTRODUCTION}

In an important publication, Straza et al. (2009) demonstrated that marine bacterioplankton from high-latitude waters are on average $30 \%$ larger than bacteria from low-latitude waters. They hypothesised that differences in the abundance of specific bacterial groups drove the observed difference in cell volume. The observation raises the question, in a more general ecological context, of how water temperature may structure the bacterioplankton community, in terms of both cell volume and species composition.

The effect of temperature on the bacterioplankton community is usually inferred from studies in areas with annual temperature variation, and seasonal changes in bacterial community composition have been reported in many areas (Lee \& Fuhrman 1991, Pinhassi \& Hagström 2000, Crump \& Hobbie 2005, Hewson et al. 2006). Temperature can play multiple roles in the apparent succession. First, the range of temperatures over which bacteria can reproduce differs among species, reflecting physiological adaptation to temperature (Nedwell 1999). In the temperature range within which a particular species grows, a crucial competitive parameter is the maximum growth rate $\left(\mu_{\max }\right)$, a property that is substrate-, species-, and temperature-specific (Herbert \& Bell 1977). The highest $\mu_{\max }$ is therefore reached 
at an optimum growth temperature, which is yet another species-specific property, meaning that some bacterial populations perform better (i.e. grow faster) than others at a given temperature. Because the optimum growth temperature and slope of response to temperature differs among bacterial populations, a population that is most successful at $10^{\circ} \mathrm{C}$ will not necessarily dominate at $20^{\circ} \mathrm{C}$ (Harder \& Veldkamp 1971). Considering the profound effect of temperature on growth capacity and rate, one might expect temperature to be an important selective determinant of the composition of bacterial communities in situ.

It is well known that a fast-growing bacterial cell is generally larger than a slow-growing cell because growth rate is exponentially related to mass, largely due to increasing amounts of RNA and DNA (Schaechter et al. 1958, Hagström 1984). Therefore, temperature can directly influence cell size in a bacterial population because increasing temperature results in higher growth rates. However, if constant growth is maintained, cell size decreases when temperature increases because enzymatic reactions become faster, and thus, fewer ribosomes are needed to support growth (Yun et al. 1996). Interestingly, seasonal studies of bacterioplankton cell volumes indicate a divergent relationship between temperature and bacterial cell volume. In the northern Baltic Sea, for example, the average cell volume of bacterioplankton is smaller in the warmer season (Hagström \& Larsson 1984, Andersson et al. 1986), in accordance with the lowlatitude observations of Straza et al. (2009). However, along the Canadian west coast, in the northeastern Mediterranean, and in the Adriatic Sea, bacterioplankton cells are larger in the warmer summer season (Albright \& McCrae 1987, Ribes et al. 1999, La Ferla \& Leonardi 2005). The challenge in interpreting in situ results is that temperature acts in concert with other selective pressures, such as grazing (Andersson et al. 1986, Sherr \& Sherr 2002) and the quality and relative amount of substrate (Young 2007, Løvdal et al. 2008), factors that also affect the community composition and cell size of individual species.

In the present study, we isolated the effect of temperature on the cell volume, cell shape, and community composition of a bacterioplankton community. We did this by studying a multi-species community grown at different temperatures, on identical seawater substrate, while maintaining a constant growth rate by using a continuous culture experimental set-up.

\section{MATERIALS AND METHODS}

To investigate the effect of temperature on the bacterial cell volume and community composition, 4 continuous seawater cultures harbouring a multi-species bacterial community were run at identical turnover times but different temperatures for $2 \mathrm{wk}$ (Fig. 1). The continuous cultures were allowed to stabilise for $1 \mathrm{wk}$, and bacterial cell volume, shape, and DNA community analyses were conducted on Days 7, 10, and 14 of the experiment.

\section{Sample collection}

Seawater used as medium and inoculum was collected at a depth of $2 \mathrm{~m}$ in the Baltic Sea on the east coast of Öland $\left(57^{\circ} 27^{\prime} \mathrm{N}, 17^{\circ} 05^{\prime} \mathrm{E}\right.$ to $56^{\circ} 56^{\prime} \mathrm{N}$, $16^{\circ} 54^{\prime} \mathrm{E}$ ) using a Niskin bottle on 25 June 2008. The in situ water temperature was $15^{\circ} \mathrm{C}$. The samples were kept in 201 polycarbonate bottles and processed within $1.5 \mathrm{~h}$.

\section{Medium preparation}

Seawater used as medium was pre-filtered through a $3.0 \mu \mathrm{m}$ pore-size polycarbonate filter (Whatman) and thereafter filtered through $0.22 \mu \mathrm{m}$ pore-size Sterivex filters (Millipore) using a peristaltic pump $\left(\sim 100 \mathrm{ml} \mathrm{min}^{-1}\right)$. Both filters were changed occasionally to avoid clogging. The filtered water was autoclaved and stored in polycarbonate bottles at $4{ }^{\circ} \mathrm{C}$.

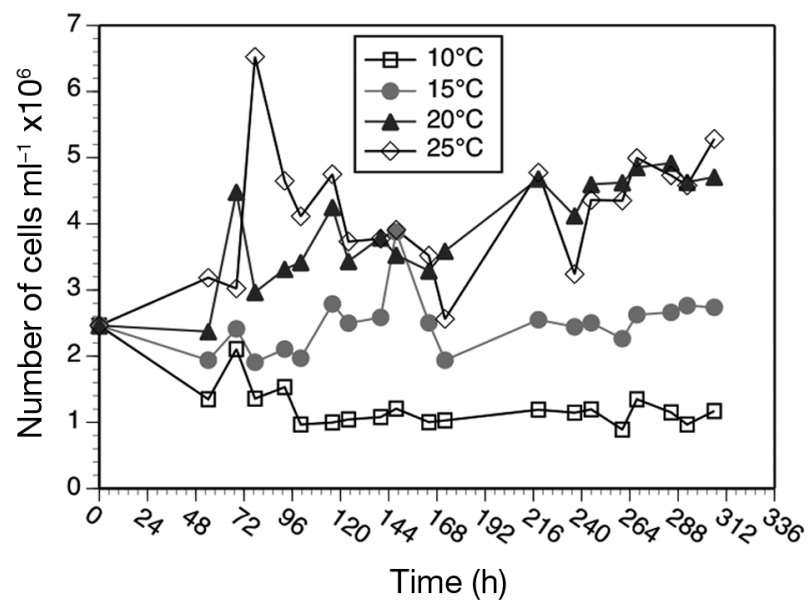

Fig. 1. Time course of cell abundance during the experiment. The continuous cultures were allowed to stabilize for 1 wk before sampling on Days 7, 10, and 14 


\section{Inoculum preparation}

The inoculum was prepared using gravity filtration through a $3.0 \mu \mathrm{m}$ pore-size polycarbonate pre-filter (Whatman) and then consecutively through two $0.6 \mu \mathrm{m}$ pore-size polycarbonate filters (Whatman). The inoculum was stored at $4{ }^{\circ} \mathrm{C}$ for $24 \mathrm{~h}$ until inoculation of the continuous seawater cultures.

\section{Experimental design}

In continuous cultures, the cell growth rate is controlled by the dilution rate, so it is possible to vary the temperature without altering the growth rate. Four continuous cultures were incubated in the dark at 4 different temperatures, i.e. $10^{\circ} \mathrm{C}, 15^{\circ} \mathrm{C}, 20^{\circ} \mathrm{C}$, and $25^{\circ} \mathrm{C}$, at a constant dilution rate of $0.04 \mathrm{~h}^{-1}$. This dilution rate corresponds to estimates of the in situ turnover time of bacterioplankton in the southern Baltic Sea at temperatures of 10 to $18^{\circ} \mathrm{C}$ (Zweifel 1999). Each continuous culture was started with $250 \mathrm{ml}$ of inoculum, which was diluted to $500 \mathrm{ml}$ by the incoming water. The incoming water was fed in drops into the culture through a sealed glass tube to prevent back growth (Hagström et al. 1984). Air was passed through a $0.2 \mu \mathrm{m}$ pore-size PTFE Acrodisc CR filter (Pall Corporation) and used to force the inflow into the cultures to prevent a water column from building up in the glass tube. A gentle flow of air was maintained to allow bubbles to be continuously produced and to stir the culture (Hagström et al. 1984, Zweifel et al. 1996). The experiment was run for $14 \mathrm{~d}$. The continuous cultures were allowed to stabilise and reach a constant cell number for $1 \mathrm{wk}$. Samples for cell counts were collected twice a day. Bacterial cell volume, shape, and DNA community analyses were conducted on Days 7, 10, and 14 of the experiment.

\section{Bacterial numbers, cell volume, and biomass}

Samples for cell counts were collected from the outflow of the continuous cultures twice a day. The samples were preserved with $4 \%$ (wt/vol) formaldehyde for a minimum of $24 \mathrm{~h}$ and filtered onto $0.2 \mu \mathrm{m}$ pore-size black polycarbonate filters (GE Water \& Process Technologies) and stained with SYBR Gold (Invitrogen, final conc. 1×). Either 200 cells or 30 fields per filter were counted at $1250 \times$ magnification using an Axioplan epifluorescence microscope (Zeiss).

Samples for determination of the cell volume were collected on Days 7, 10, and 14; they were preserved and filtered in the same way as samples for cell enumeration but stained with $0.1 \%$ (wt/vol) acridine orange. Images were acquired using a CCD camera connected to an Axioplan epifluorescence microscope (Zeiss), and the cell volumes were determined using an image analysis system (LabMicrobe, BioRAS DK). The volume $(V)$ was calculated according to the formula $V=\left[\left(4 \pi r^{3} / 3\right)+\pi r^{2}(1-2 r)\right]$ (Blackburn et al. 1998), where $r$ is the radius (calculated by the program from the area and the length, 1). Three morphological groups, i.e. cocci, rods, and vibrios, were identified by the image recognition system of the software. The cell volume and abundance of morphological groups were determined from 10 photomicrographs at each temperature each sampling day. Total biomass yield is the product of abundance and volume and was calculated from the estimated cell volumes and total cell counts (Chrzanowski et al. 1988).

\section{Statistics}

Data for cell volumes were divided into the 3 morphological groups, i.e. cocci, rods, and vibrios. Statistical analysis were performed to evaluate whether the size of each morphotype at each temperature changed between sampling occasions, whether there was a significant difference in cell volume between the 3 morphotypes, and whether the abundance of each morphotype was significantly different at different temperatures. The samples were checked for normal distribution using a Shapiro-Wilk normality test. The abundances of rods and vibrios at different temperatures were normally distributed, and the difference in abundance of these morphologies was investigated using analysis of variance followed by a post-hoc Tukey's test. The abundances of cocci and biovolumes of each morphology at different temperatures were not normally distributed, and the differences were therefore investigated using a KruskalWallis test followed by a post-hoc analysis using Mann-Whitney tests with Bonferroni corrections.

The cell volumes changed significantly between sampling Occasions 1 and 3, indicating that the community had not reached steady state on the first sampling occasion. Between sampling Occasions 2 and 3, there was no significant difference in 9 out of 12 cases, indicating that steady state was progressively being reached. Statistics regarding the size and abundance of morphotypes were therefore based on results from sampling Occasion 3, i.e. Day 14 of the experiment, for all temperatures. 
DNA extraction and denaturing gradient gel electrophoresis (DGGE) analysis of community DNA

Samples for DNA extraction from the continuous cultures were prepared by filtering $100 \mathrm{ml}$ of water from the outflow of the chemostat through $0.2 \mu \mathrm{m}$ pore-size filters $25 \mathrm{~mm}$ in diameter (Supor filter, Pall Corporation). The filters were stored at $-20^{\circ} \mathrm{C}$ until extraction. Samples from Days 7, 10, and 14 were chosen for DNA extraction and DGGE analysis.

DNA samples from the continuous cultures were extracted according to Fuhrman et al. (1988) as optimised by Boström et al. (2004). After lysis and incubation with sodium dodecyl sulphate, DNA was extracted once with $500 \mu \mathrm{l}$ of phenol/chloroform/ isoamylalcohol $(25: 24: 1)$ and once with $600 \mu \mathrm{l}$ of chloroform/isoamylalcohol (24:1) before ethanol precipitation.

Bacterial 16S rRNA genes were PCR amplified using primers GC341F (complementary to positions 341-358 with a 40 bp GC clamp) (Muyzer et al. 1993) and 907R (complementary to positions 907-927) (Muyzer et al. 1998) and quantified using PicoGreen (Molecular Probes). A total of $90 \mathrm{ng}$ of PCR product was analysed using DGGE with the D Gene System (Bio-Rad) at $60^{\circ} \mathrm{C}$ for $6 \mathrm{~h}$ at $150 \mathrm{~V}$. Gels were stained with SYBR Gold (Invitrogen).

The DGGE banding pattern in each lane was converted into a binary matrix indicating the presence (scored as 1) or absence (scored as 0) of each band in all lanes. Distance matrices for all pair-wise combinations were constructed using the Dice coefficient and used as input for multidimensional scaling (MDS). The MDS was performed with Primer v6.

\section{RESULTS AND DISCUSSION}

\section{Effect of temperature on community structure and cell volume}

Changes in the community composition were clearly demonstrated using DGGE (Fig. 2A). This method can identify community constituents that represent $\geq 1 \%$ of the community, and several studies have demonstrated that DGGE band intensity can be used as a rough estimate of the relative abundance of these phylotypes (Riemann et al. 1999, Casamayor et al. 2000). The DGGE banding pattern from the continuous culture indicated a shift in the bacterial community composition along the temperature gradient, i.e. a different set of phylotypes came to dominate the cultures, although some phylotypes (i.e. DGGE bands) were shared at all temperatures (Fig. 2A). The community composition at $10^{\circ} \mathrm{C}$ changed from Days 7 to 10 of the experiment but then stabilised, while the communities at $20^{\circ} \mathrm{C}$ and $25^{\circ} \mathrm{C}$ were dominated by the same phylotypes and seemed to have already stabilised on Day 7 . The MDS constructed from the banding patterns on the DGGE gel (Fig. 2B) shows that the samples from the $10^{\circ} \mathrm{C}, 20^{\circ} \mathrm{C}$, and $25^{\circ} \mathrm{C}$ cultures formed distinct clusters, whereas the first 2 samples from the $15^{\circ} \mathrm{C}$ culture clustered separately, and the third sample clus-
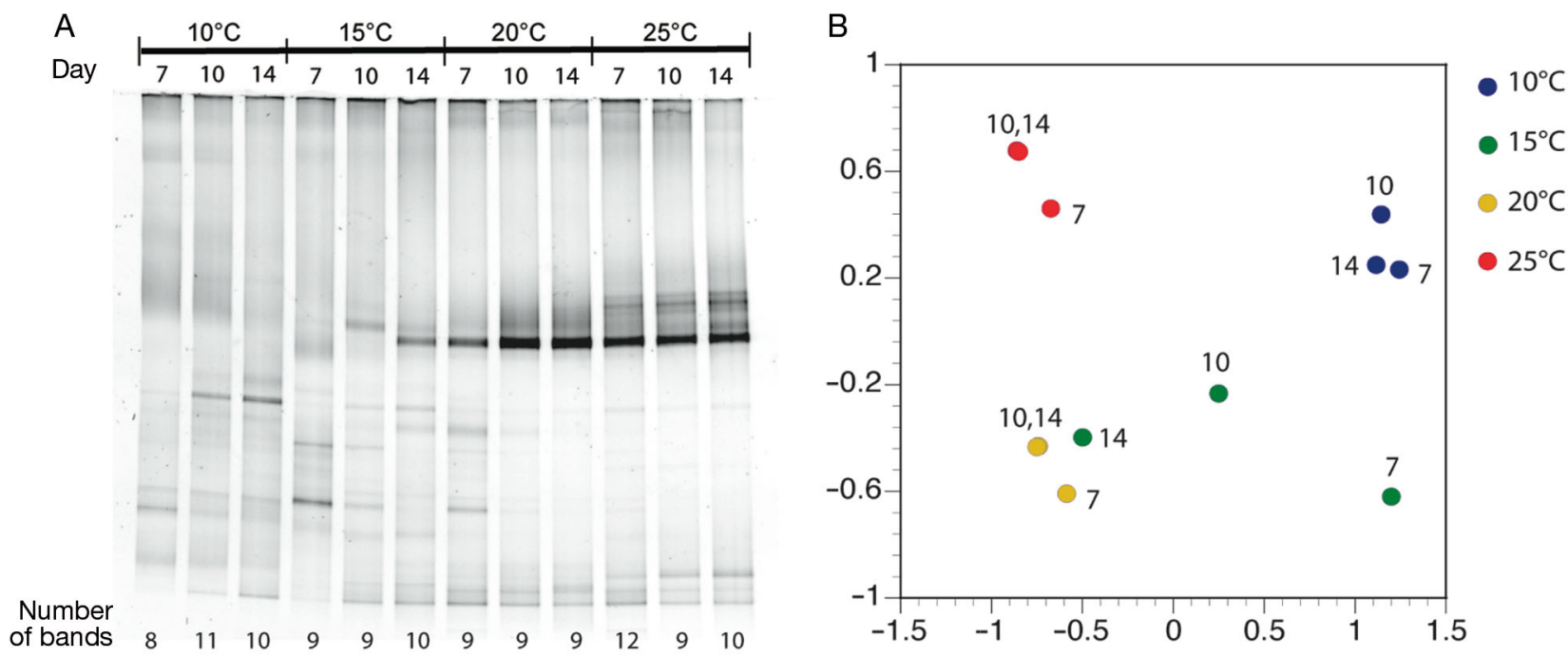

Fig. 2. (A) Bacterial phylotype richness in the continuous cultures kept at different temperatures recorded using DGGE; (B) MDS from DGGE banding patterns at different temperatures. The numbers $(7,10$, and 14) indicate the day of sampling at each temperature. At $20^{\circ} \mathrm{C}$ and $25^{\circ} \mathrm{C}$, Days 10 and 14 can barely be separated from each other 
tered with the samples from the $20^{\circ} \mathrm{C}$ culture. Thus, the growth conditions seemed to favour stable communities at each end of the temperature range, one cold-adapted and one warm-adapted group. Note that the in situ temperature when the inoculum was collected was $15^{\circ} \mathrm{C}$, while the minimum, maximum, and average temperatures in the near-surface waters of the Baltic Proper are $2^{\circ} \mathrm{C}, 19^{\circ} \mathrm{C}$, and $7.4^{\circ} \mathrm{C}$, respectively (Siegel et al. 2006).

The volume and shape of the individual cells were determined from digital photomicrographs using image analysis (Fig. 3). On average, on each sampling occasion, 470 cells were included in the analysis at $10^{\circ} \mathrm{C}, 695$ cells at $15^{\circ} \mathrm{C}, 860$ cells at $20^{\circ} \mathrm{C}$, and 1374 cells at $25^{\circ} \mathrm{C}$. The differences in number of counted cells are due to differences in bacterial abundances in the different treatments. Overall, the average cell volume of the community decreased

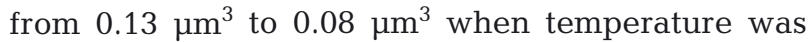
increased from $10^{\circ} \mathrm{C}$ to $20^{\circ} \mathrm{C}$, corresponding to an average decrease in biovolume of $39 \%$ (Fig. 4). Fixation with formaldehyde can cause cell shrinkage, and even if shrinkage occurs in all size classes, it is possible that larger cells are subjected to greater shrinkage (Fuhrman 1981). For ciliates, it has been demonstrated that the cell volume shrinkage differs among species in closely related taxa (Choi \& Stoecker 1989). Similar effects cannot be excluded for bac-
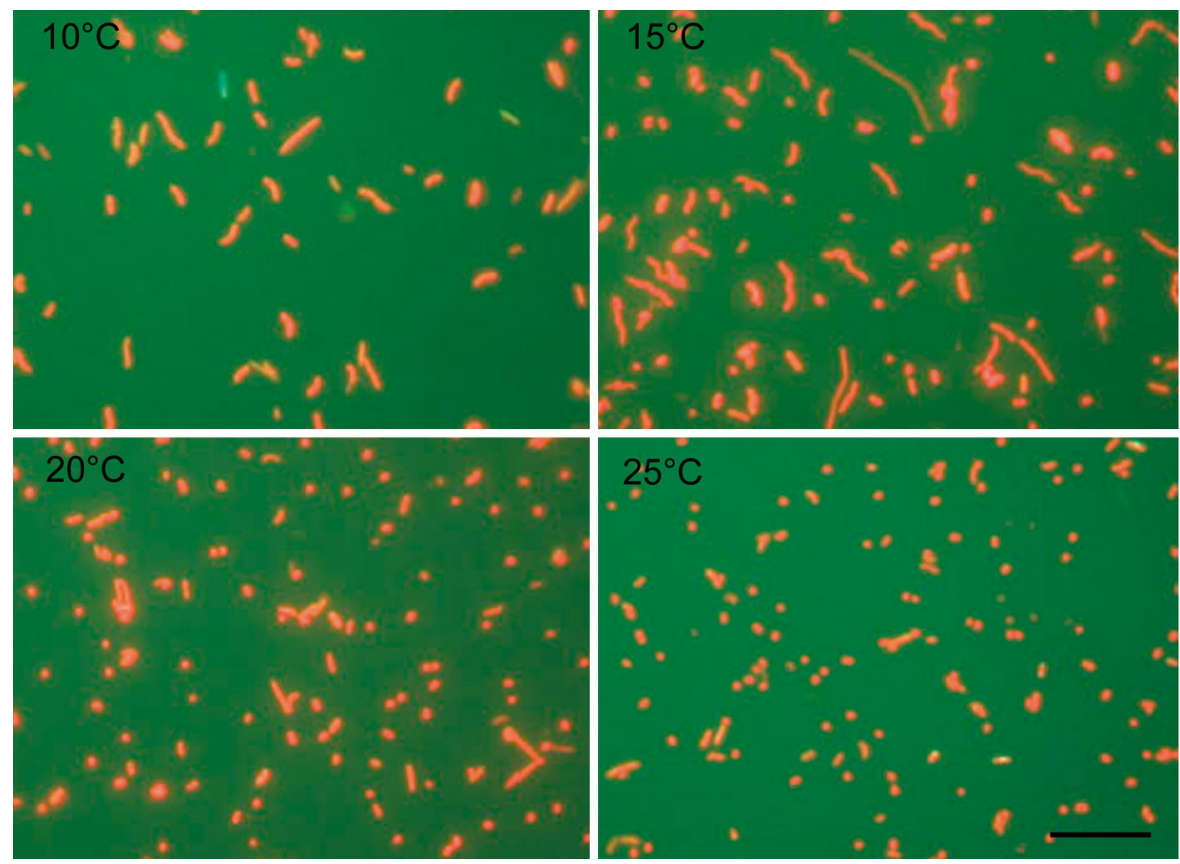

Fig. 3. Photomicrographs of different temperature treatments taken using a digital camera connected to an epifluorescence microscope. Fixation and acridine orange staining were conducted on Day 10 of the experiment. Scale bar $=10 \mu \mathrm{m}$

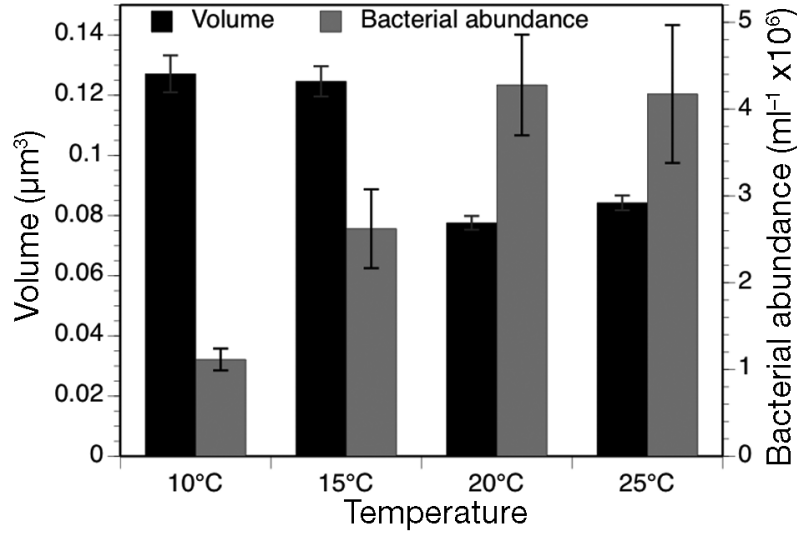

Fig. 4. Effects of increasing temperature on average cell volume $\left(\mu^{3}\right)$ and bacterial abundance in 4 multispecies cultures growing at an identical turnover time but at different temperatures. Bars indicate standard error; the data are average values from sampling Occasion 3

teria. However, the effect of shrinkage would probably be comparable among the different samples, and the cell sizes underestimated at all temperatures.

In addition to a change in cell volume, image analysis revealed that the cell morphology changed significantly in the continuous cultures, with the fraction of coccoid cells increasing from on average $42 \%$ at $10^{\circ} \mathrm{C}$ to on average $66 \%$ at $25^{\circ} \mathrm{C}(\mathrm{p}<0.01)$ (Fig. 5A), while rod-shaped cells dropped from $44 \%$ to $22 \%(\mathrm{p}<0.01)$ of the total number.

Taken together, the DGGE and image analysis revealed that a shift in temperature selected for smaller and differently shaped cells and the dominance of new phylotypes. Because the DGGE results indicated that the different cultures harboured both omnipresent and new dominant phylotypes, we speculate that this temperature-related succession may have been caused by (1) omnipresent phylotypes in the cultures becoming smaller by adapting to the higher temperature and/or (2) inherently small phylotypes becoming dominant in the community. This in turn raises 2 questions: (1) Why would a specific phylotype become smaller at higher 

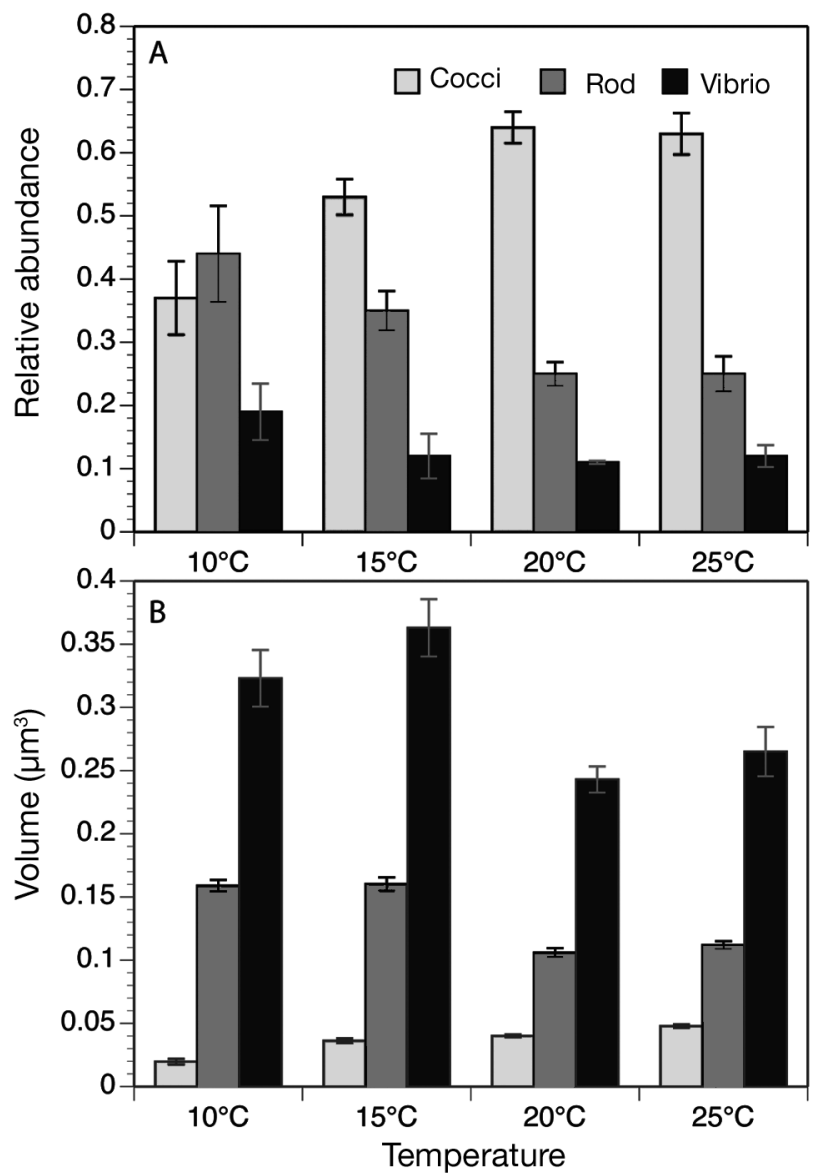

Fig. 5. (A) Abundance and (B) average cell volumes $\left(\mu \mathrm{m}^{3}\right)$ of the 3 morphological types, i.e. cocci, rods, and vibrios, at different temperatures. The data are average values from sampling Occasion 3; bars indicate standard error

temperature? (2) What favours a community with smaller dominant phylotypes at higher temperature? If we first address the phylotype-specific perspective, the decrease in average cell volume at higher temperatures in our experiment can be explained by a fundamental bacterial growth response. Ribosomes are a substantial part of the bacterial cell. In Escherichia coli, the ribosomes are composed of $38 \%$ proteins and $62 \%$ rRNA. In an average E. coli, rRNA contributes to $16 \%$ of the total dry weight and the ribosomes to $\sim 25 \%$ of the total dry weight (Neidhardt et al. 1990a,b). Schaechter et al. (1958) found that, in Salmonella thyphimurium, the amount of protein synthesised per minute is roughly proportional to the RNA content of the cell and that the number of protein molecules synthesised per minute is constant at a given temperature irrespective of growth rate. Thus, the cell adjusts its number of ribosomes so that it has the number needed to match the growth potential of the substrate. Although the work by
Schaechter et al. was done using a model organism grown in rich media, we believe that these mechanisms are commonly also used by marine bacteria to adjust protein synthesis rates. In the continuous culture experiment, the amount of added substrate and turnover time (growth rate) remained the same while temperature increased. Because enzymatic reactions, such as ribosome activity, are faster at a higher temperature, fewer functional ribosomes are needed for the same function, as has been demonstrated for E. coli (Yun et al. 1996, Cotner et al. 2006), so the cell can be expected to become smaller. A decreased RNA content per cell with increased temperature at a specific growth rate, i.e. conditions identical to those of continuous cultures, has also been demonstrated in the case of Aerobacter aerogenes (Tempest \& Hunter 1965). It has also been suggested that the cells optimise the ratio between nutrient acquisition and cell assembly machinery with temperature because of differences in the temperature dependence of various processes. Because growth is more temperature-dependent than diffusion, more resources are used for assembly relative to nutrient acquisition at colder temperatures (Cotner et al. 2006). An additional argument for the increasing bacterial cell size at lower temperature is that DNA replication also is a temperature-dependent enzymatic process, which is slower at lower temperature. The relationship between cell size and growth rate seems to depend on the necessity of attaining a particular mass to initiate replication of the chromosome (Donachie 1968). To be able to grow at the same dilution rate at $10^{\circ} \mathrm{C}$ as at $20^{\circ} \mathrm{C}$, more than one round of replication must be going on simultaneously, and therefore, a higher mass is needed (Donachie 1968).

Alternatively, or likely in parallel, increased temperature selected for a community of inherently smaller species in the continuous cultures run at higher temperatures. According to the common paradigm, small cells have a competitive advantage in terms of nutrient uptake because they have a higher surface-to-volume ratio (Kirchman 2008). In the cultures, there was a clear positive relationship between cell numbers and temperature up to $20^{\circ} \mathrm{C}$. In the $10^{\circ} \mathrm{C}$ and $15^{\circ} \mathrm{C}$ cultures, cell numbers were $1.1 \times$ $10^{6} \pm 1.3 \times 10^{5}$ and $2.6 \times 10^{6} \pm 4.5 \times 10^{5}$ cells ml $^{-1}$, respectively, while at the 2 highest temperatures, the cell numbers were $4.3 \times 10^{6} \pm 5.8 \times 10^{5} \mathrm{cells} \mathrm{m}^{-1}$ at $20^{\circ} \mathrm{C}$ and $4.2 \times 10^{6} \pm 7.9 \times 10^{5}$ cells ml ${ }^{-1}$ at $25^{\circ} \mathrm{C}$ (Fig. 4). Thus, the growth yield, or number of cells, plateaued between $20^{\circ} \mathrm{C}$ and $25^{\circ} \mathrm{C}$. We propose that this observation relates to the bacterioplankton growth shifting from temperature to resource limita- 
tion above 15 to $20^{\circ} \mathrm{C}$, as suggested by Apple et al. (2006).

A notable result in relation to cell morphology was that the volume of coccoid cells was significantly smaller than those of vibrio- (82 to $94 \%$ ) or rodshaped cells $(57$ to $88 \%)$ at all temperatures $(p<0.01)$ (Fig. 5B). For bacteria of the same volume, it is advantageous to be rod-shaped rather than spherical because the rod shape provides a higher surfaceto-volume ratio and therefore gives a competitive advantage in terms of nutrient uptake (Koch 1995, Kirchman 2008). The results may indicate that, irrespective of species-specific properties, coccoid species can only compete for resources in a multi-species community when they are inherently small.

\section{Effect of temperature on bacterial biomass}

Although the bacterial cell size decreased with increasing temperature, the total biomass was positively related to temperature because of the higher bacterial abundance at higher temperature. If we assume constant carbon content per volume, for example, $0.22 \mathrm{~g} \mathrm{C} \mathrm{cm}^{-3}$ (Bratbak \& Dundas 1984), the total biomass was $31.3 \mathrm{ng} \mathrm{ml}^{-1}$ at $10^{\circ} \mathrm{C}$ and increased to $97.9 \mathrm{ng} \mathrm{ml}^{-1}$ at $25^{\circ} \mathrm{C}$. Moreover, Trousselier et al. (1997) have demonstrated that the carbon content relative to cell volume is higher for smaller than larger cells. This would imply that using a constant carbon volume underestimates the biomass more at higher temperatures due to the higher proportion of small cells and that the actual difference in biomass between the 2 temperature extremes is even larger.

The reason for an increase in biomass can be either higher growth efficiency or increased nutrient use efficiency. It has been shown that bacteria have an increased affinity for DOM (dissolved organic matter) at higher temperatures (Kirchman \& Rich 1997) and that warm-adapted bacterial communities respond to increasing temperature by increasing nutrient use efficiency, probably because of increased kinetic energy of ribosomes and other cellular 'machinery' involved in biomass synthesis (Hall et al. 2009).

\section{Effect of temperature on cell size and morphology in situ}

How can our results be interpreted in relation to in situ observations of changed size and morphology of bacterioplankton? First, our results are based on maintaining constant growth rate at increasing temperature, a case that is rare in nature. However, several in situ observations suggest that temperature may be a strong selective factor for smaller cell size. As outlined in the introduction, Straza et al. (2009) have demonstrated that bacterioplankton from lowlatitude waters are smaller than those from high-latitude waters. On a seasonal scale, bacterioplankton in Lake Arlington (Texas, USA) and the northern Baltic Sea (Bothnian Sea) have been found to be smaller in summer, coinciding with the highest annual temperature of the water mass (Andersson et al. 1986, Chrzanowski et al. 1988). However, in contrast to our results, the cell volume of bacteria in several marine sea areas has been found to increase during seasons associated with higher temperature, for example, in Howe Sound (a Canadian west coast fjord) and the Adriatic Sea (Albright \& McCrae 1987, La Ferla \& Leonardi 2005). A study conducted in 20 stratified lakes in the USA showed that cell size was independent of temperature under both oxic and anoxic conditions. However, the bacteria were 2 to 10 times larger in the anoxic hypolimnia than in the oxic water. This shows that factors other than temperature can affect cell size. The anoxic hypolimnia is usually rich in organic and inorganic nutrients, which is one factor that may promote larger cell size (Cole et al. 1993). Opposing in situ observations can likely be explained by the multiple factors affecting the volume of cells in situ, factors that partly act in opposing directions. In summer, in situ bacterial growth rates and predation are generally at their yearly maximum, while nutrient limitations are becoming more pronounced (Zweifel 1999). A higher growth rate will tend to increase the biovolume of cells due to increased mass of intracellular components (Schaechter et al. 1958), while nutrient limitations, predation (Andersson et al. 1986), and higher temperature, as outlined here, will favour smaller cells. In the Baltic Sea and Lake Arlington, the sum of factors was apparently advantageous for smaller cells, either selecting for a new community composed of small species or promoting a reduction in the size of omnipresent species.

In a model, it has been shown that the effect of increasing temperature on bacterial community composition and bacterially mediated biogeochemical processes is linked to the resource stoichiometry of a given aquatic system (Hall et al. 2008). It is possible that changes in size in relation to temperature also depend on the resource stoichiometry of the aquatic system. We speculate that increased cell size in summer may be related to unbalanced nutrient and car- 
bon dynamics. While nutrient limitations generally tend to favour small cells, some bacteria can store excess carbon in the form of, for example, polysaccharides, increasing the cell volume under $\mathrm{N}$ - and/or P-limited conditions (Zweifel et al. 1993, Thingstad et al. 2005). A bacterial species with this ability, Vibrio splendidus, has been found to transform itself from coccoid cells in C-limited cultures (grown on glucose) into large rod-shaped cells in P-limited cultures, while being maintained at constant growth rate (Løvdal et al. 2008). Observations from the Adriatic Sea are consistent with this shift. In summer, the Adriatic Sea is strongly P-limited, and large cell volumes and a predominance of rod- and vibrio-shaped bacteria have been observed (Thingstad et al. 1998, La Ferla \& Leonardi 2005). In contrast, in winter, when bacterial growth is presumably more C-limited, a proportionate increase in coccoid cells has been recorded (La Ferla \& Leonardi 2005).

\section{Effect of grazers on cell size and morphology}

Grazing is a selective pressure known to affect bacterial cell size (Andersson et al. 1986, Sherr \& Sherr 2002). In the continuous cultures, grazers, such as flagellates and ciliates, were removed by filtration, and only virus-mediated mortality could have affected the cell size and morphology. Virus-mediated mortality of prokaryotes in the water column is often in the range of 10 to $30 \%$, and different studies have shown that viral lysis can be a source of prokaryotic mortality comparable to or even higher than bacterivory by protists (reviewed by Danovaro et al. 2011). The abundance of marine viruses is closely linked to bacterial abundance and is affected by physical and chemical characteristics of the water, e.g. temperature and salinity, because these factors have an effect on the abundance of bacteria (reviewed by Danovaro et al. 2011). Because viruses are usually species- or strain-specific (Børsheim 1993), they might influence the bacterial community composition by controlling the abundant species or strains. It has been shown that prokaryotic heterotrophic production increases with increasing temperature up to $\sim 15^{\circ} \mathrm{C}$ (Apple et al. 2006), and as growth rate increases, the length of the lytic cycle decreases and burst-size increases, leading to higher rates of virus production (Proctor et al. 1993, Hadas et al. 1997). Using phage isolates, it has been demonstrated that the injection of phage DNA is temperature dependent, which may be related to the optimal growth temperature of the host (Giladi et al. 1995).
The potential effect of viral lysis on cell size distribution has not been studied to a larger extent. In a model describing the random encounters of viruses and particles, it is concluded that for any given viral concentration the contact rates will be higher for larger and motile particles. However, the model only describes the probability of encountering a particle, not the infection rate (Murray \& Jackson 1992). In a field study in Lake Plußsee (Germany) of the sizespecific mortality due to viruses, in all depth layers, most of the visibly infected cells belonged to the size class $0.6-0.9 \mu \mathrm{m}$ in length, and the virus-induced mortality was between 42 and $81 \%$ within this size class (Weinbauer \& Höfle 1998). Differences in viral infection frequencies among bacterial morphotypes have also been demonstrated. In a collapsed diatom bloom, the decrease in bacterial abundance was due to a decrease in the population of cocci, whereas the number of rods and curved rods per diatom cell remained the same. The phage population was homogenous in morphology and size, which indicate that a single phage-host system was dominating and that cocci were the host bacteria (Bratbak et al. 1990). In addition, 2 studies from the northern Adriatic Sea have shown that coccoid bacteria more frequently contained mature phages than rod-shaped bacteria and spirillae (Weinbauer \& Peduzzi 1994, 1995). In contrast, when the viral infection rates of different morphotypes were investigated in Lake Créteil (France), rods were the most dominant morphotype and also contained the largest fraction of infected cells (Ram et al. 2010). The different infection rates of various morphotypes and size classes suggest that viruses can have a significant impact on bacterial community composition.

\section{Conclusion}

Our results indicate that the average cell volume of bacteria decreased and the abundance of cocci increased in response to increasing temperature. This result was caused by a shift in the bacterioplankton community composition, possibly in combination with a diminution in the size of omnipresent bacteria. The importance of temperature as a selective factor for community composition and for the cell volume and shape of marine bacteria was clearly demonstrated.

Acknowledgements. This work was supported by the Swedish National Science Council, VR (grant 621-20085385), and by the School of Pure and Applied Natural Sciences, University of Kalmar, Sweden. We thank the participants in 
the MarBEF course 'Growing and isolating marine microbes: cultured and uncultured', Kalmar 2008, for inspiration and help with the test experiment. We are grateful to L. Riemann and 3 anonymous reviewers for valuable comments on the manuscript.

\section{LITERATURE CITED}

Albright LJ, McCrae SK (1987) Annual cycle of bacterial specific biovolumes in Howe Sound, a Canadian west coast fjord sound. Appl Environ Microbiol 53:2739-2744

> Andersson A, Larsson U, Hagström Å (1986) Size-selective grazing by microflagellates on pelagic bacteria. Mar Ecol Prog Ser 33:51-57

Apple J, del Giorgio PA, Kemp M (2006) Temperature regulation of bacterial production, respiration, and growth efficiency in a temperate salt-marsh estuary. Aquat Microb Ecol 43:243-254

Blackburn N, Hagström Å, Wikner J, Cuadros-Hansson R, Koefoed Bjornsen P (1998) Rapid determination of bacterial abundance, biovolume, morphology, and growth by neural network-based image analysis. Appl Environ Microbiol 64:3246-3255

Børsheim KY (1993) Native marine bacteriophages. FEMS Microbiol Ecol 102:141-159

> Boström HK, Simu K, Hagström Å, Riemann L (2004) Optimization of DNA extraction for quantitative marine bacterioplankton community analysis. Limnol Oceanogr Methods 2:365-373

Bratbak G, Dundas I (1984) Bacterial dry matter content and biomass estimations. Appl Environ Microbiol 48:755-757

> Bratbak G, Heldal M, Norland S, Thingstad TF (1990) Viruses as partners in spring bloom microbial trophodynamics. Appl Environ Microbiol 56:1400-1405

> Casamayor EO, Schafer H, Baneras L, Pedrós-Alió C, Muyzer G (2000) Identification of and spatio-temporal differences between microbial assemblages from two neighboring sulfurous lakes: comparison by microscopy and denaturing gradient gel electrophoresis. Appl Environ Microbiol 66:499-508

> Choi JW, Stoecker DK (1989) Effects of fixation on cell volume of marine planktonic protozoa. Appl Environ Microbiol 55:1761-1765

> Chrzanowski TH, Crotty RD, Hubbard GJ (1988) Seasonal variation in cell volume of epilimnetic bacteria. Microb Ecol 16:155-163

> Cole JJ, Pace ML, Caraco NF, Steinhart GS (1993) Bacterial biomass and cell size distribution in lakes: more and larger cells in anoxic waters. Limnol Oceanogr 38: 1627-1632

> Cotner JB, Makino W, Biddanda BA (2006) Temperature affects stoichiometry and biochemical composition of Escherichia coli. Microb Ecol 52:26-33

> Crump BC, Hobbie JE (2005) Synchrony and seasonality in bacterioplankton communities of temperate rivers. Limnol Oceanogr 50:1718-1729

> Danovaro R, Corinaldesi C, Dell'anno A, Fuhrman JA, Middelburg JJ, Noble RT, Suttle CA (2011) Marine viruses and global climate change. FEMS Microbiol Rev 35: 993-1034

> Donachie WD (1968) Relationship between cell size and time of initiation of DNA replication. Nature 219: 1077-1079

Fuhrman JA (1981) Influence of method and the apparent size distribution of bacterioplankton cells: epifluorescence microscopy compared to scanning electron microscopy. Mar Ecol Prog Ser 5:103-106

Fuhrman JA, Comeau DE, Hagström Å, Chan AM (1988) Extraction from natural planktonic microorganisms of DNA suitable for molecular biological studies. Appl Environ Microbiol 54:1426-1429

- Giladi H, Goldenberg D, Koby S, Oppenheim AB (1995) Enhanced activity of bacteriophage $\lambda P_{\mathrm{L}}$ promoter at low temperature. Proc Natl Acad Sci USA 92:2184-2188

Hadas H, Einav M, Fishov I, Zaritsky A (1997) Bacteriophage T4 development depends on the physiology of its host Escherichia coli. Microbiology 143:179-185

Hagström $\AA$ (1984) Aquatic bacteria: measurements and significance of growth. In: Klug MJ, Reddy CA (eds) Current perspectives in microbial ecology. Proc 3rd Int Symp Microb Ecol, Michigan State University, 7-12 August 1983. American Society for Microbiology, Washington, DC, p 495-501

Hagström $\AA$, Larsson U (1984) Diel and seasonal variation in growth rates of pelagic bacteria. In: Hobbie JE, Williams PJ (eds) Heterotrophic activity in the sea. Plenum Press, New York, NY, p 249-263

- Hagström Å, Ammerman JW, Henrichs S, Azam F (1984) Bacterioplankton growth in seawater: II. Organic matter utilization during steady-state growth in seawater cultures. Mar Ecol Prog Ser 18:41-48

> Hall EK, Neuhauser C, Cotner JB (2008) Toward a mechanistic understanding of how natural bacterial communities respond to changes in temperature in aquatic ecosystems. ISME J 2:471-481

Hall EK, Dzialowski AR, Stoxen SM, Cotner JB (2009) The effect of temperature on the coupling between phosphorus and growth in lacustrine bacterioplankton communities. Limnol Oceanogr 54:880-889

Harder W, Veldkamp H (1971) Competition of marine psychrophilic bacteria at low temperatures. Antonie van Leeuwenhoek 37:51-63

Herbert RA, Bell CR (1977) Growth characteristics of an obligately psychrophilic Vibrio sp. Arch Microbiol 113: 215-220

Hewson I, Steele JA, Capone DG, Fuhrman JA (2006) Temporal and spatial scales of variation in bacterioplankton assemblages of oligotrophic surface waters. Mar Ecol Prog Ser 311:67-77

Kirchman DL (2008) Introduction and overview. In: Kirchman DL (ed) Microbial ecology of the ocean, 2nd edn. Wiley-Blackwell, Hoboken, NJ, p 1-26

Kirchman DL, Rich JH (1997) Regulation of bacterial growth rates by dissolved organic carbon and temperature in the equatorial Pacific ocean. Microb Ecol 33:11-20

Koch AL (1995) Gram-positive rod-shaped organisms: Bacillus subtilis. In: Koch AL (ed) Bacterial growth and form. Chapman \& Hall, New York, NY, p 219-249

- La Ferla R, Leonardi M (2005) Ecological implications of biomass and morphotype variations of bacterioplankton: an example in the coastal zone of the northern Adriatic Sea (Mediterranean). PSZNI Mar Ecol 26:82-88

Lee S, Fuhrman JA (1991) Spatial and temporal variation of natural bacterioplankton assemblages studied by total genomic DNA cross-hybridization. Limnol Oceanogr 36: 1277-1287

Løvdal T, Skjoldal EF, Heldal M, Norland S, Thingstad TF (2008) Changes in morphology and elemental composition of Vibrio splendidus along a gradient from carbon- 
limited to phosphate-limited growth. Microb Ecol 55: 152-161

Murray AG, Jackson GA (1992) Viral dynamics: a model of the effect of size, shape, motion and abundance of single-celled planktonic organisms and other particles. Mar Ecol Prog Ser 89:103-116

Muyzer G, de Waal EC, Uitterlinden AG (1993) Profiling of complex microbial populations by denaturing gradient gel electrophoresis analysis of polymerase chain reaction-amplified genes coding for 16S rRNA. Appl Environ Microbiol 59:695-700

Muyzer G, Brinkhoff T, Nübel U, Santegoeds C, Schäfer H, Wawer C (1998) Denaturing gradient gel electrophoresis (DGGE) in microbial ecology. In: Akkermans ADL, van Elsas JD, de Bruin FJ (eds) Molecular microbial ecology manual. Kluwer Academic Publishers, London, p 1-27

Nedwell DB (1999) Effect of low temperature on microbial growth: lowered affinity for substrates limits growth at low temperature. FEMS Microbiol Ecol 30:101-111

Neidhardt F, Ingraham J, Schaechter M (1990a) Composition and organisation of the bacterial cell. In: Neidhardt F, Ingraham J, Schaechter M (ed) Physiology of the bacterial cell: a molecular approach. Sinauer Associates, Sunderland, MA, p 1-29

Neidhardt F, Ingraham J, Schaechter M (1990b) Structure and function of bacterial cell parts. In: Neidhardt $F_{\text {, }}$ Ingraham J, Schaechter M (ed) Physiology of the bacterial cell: a molecular approach. Sinauer Associates, Sunderland, MA, p 30-61

Pinhassi J, Hagström Å (2000) Seasonal succession in marine bacterioplankton. Aquat Microb Ecol 21:245-256

> Proctor LM, Okuba A, Fuhrman JA (1993) Calibrating estimates of phage-induced mortality in marine bacteria: ultrastructural studies of marine bacteriophage development from one-step growth experiments. Microb Ecol 25: 161-182

Ram AS, Arnous B, Danger M, Carrias JF, Lacroix G, SimeNgando T (2010) High and differential viral infection rates within bacterial 'morphopopulations' in a shallow sand pit lake (Lac de Creteil, France). FEMS Microbiol Ecol 74:83-92

Ribes M, Coma R, Gili J (1999) Seasonal variation of particulate organic carbon, dissolved organic carbon and the contribution of microbial communities to the live particulate organic in a shallow near-bottom ecosystem at the Northwestern Mediterranean Sea. J Plankton Res 21: 1077-1100

Riemann L, Steward GF, Fandino LB, Campbell L, Landry MR, Azam F (1999) Bacterial community composition during two consecutive NE Monsoon periods in the Arabian Sea studied by denaturing gradient gel electrophoresis (DGGE) of rRNA genes. Deep-Sea Res II 46: 1791-1811

Schaechter M, Maaløe O, Kjeldgaard NO (1958) Dependency on medium and temperature of cell size and chem-

Editorial responsibility: Josep Gasol,

Barcelona, Spain ical composition during balanced growth of Salmonella typhimurium. J Gen Microbiol 19:592-606

Sherr EB, Sherr BF (2002) Significance of predation by protists in aquatic microbial food webs. Antonie van Leeuwenhoek 81:293-308

Siegel H, Gerth M, Tschersich G (2006) Sea surface temperature development of the Baltic Sea in the period 19902004. Oceanologia 48:119-131

Straza TRA, Cotrell MT, Ducklow HW, Kirchman DL (2009) Geographic and phylogenetic variation in bacterial biovolume as evidenced by protein and nucleic acid staining. Appl Environ Microbiol 75:4028-4034

- Tempest DW, Hunter JR (1965) The influence of temperature and $\mathrm{pH}$ value on the macro-molecular composition of magnesium-limited and glycerol-limited Aerobacter aerogenes growing in a chemostat. J Gen Microbiol 41: $267-273$

> Thingstad TF, Zweifel UL, Rassoulzadegan F (1998) P limitation of heterotrophic bacteria and phytoplankton in the northwest Mediterranean. Limnol Oceanogr 43: 88-94

> Thingstad TF, Øvreås L, Egge JK, Løvdal T, Heldal M (2005) Use of non-limiting substrates to increase size: a generic strategy to simultaneously optimize uptake and minimize predation in pelagic osmotrophs? Ecol Lett 8: 675-682

> Troussellier M, Bouvy M, Courties C, Dupuy C (1997) Variation of carbon content among bacterial species under starvation condition. Aquat Microb Ecol 13:113-119

> Weinbauer MG, Höfle MG (1998) Size-specific mortality of lake bacterioplankton by natural virus community. Aquat Microb Ecol 15:103-113

- Weinbauer MG, Peduzzi P (1994) Frequency, size and distribution of bacteriophages in different marine bacterial morphotypes. Mar Ecol Prog Ser 108:11-20

- Weinbauer MG, Peduzzi P (1995) Effect of virus-rich high molecular weight concentrates of seawater on the dynamics of dissolved amino acids and carbohydrates. Mar Ecol Prog Ser 127:245-253

> Young KD (2007) Bacterial morphology: why have different shapes? Curr Opin Microbiol 10:596-600

Yun HS, Hong J, Lim HC (1996) Regulation of ribosome synthesis in Escherichia coli: effects of temperature and dilution rate changes. Biotechnol Bioeng 52: 615-624

Zweifel UL (1999) Factors controlling accumulation of labile dissolved organic carbon in the Gulf of Riga. Estuar Coast Shelf Sci 48:357-370

Zweifel UL, Norrman B, Hagström Å (1993) Consumption of dissolved organic carbon by marine bacteria and demand for inorganic nutrients. Mar Ecol Prog Ser 101: 23-32

> Zweifel UL, Blackburn N, Hagström Å (1996) Cycling of marine dissolved organic matter. I. An experimental system. Aquat Microb Ecol 11:65-77

Submitted: September 16, 2011; Accepted: June 6, 2012

Proofs received from author(s): June 29, 2012 